\title{
Aphid individual performance may not predict population responses to elevated $\mathrm{CO}_{2}$ or $\mathrm{O}_{3}$
}

\author{
CAROLINES. AWMACK*†, RICHARD HARRINGTON† and RICHARD L. LINDROTH* \\ *Department of Entomology, University of Wisconsin-Madison, 1630 Linden Drive, Madison, WI 53706, USA and \\ $\dagger$ Plant and Invertebrate Ecology Division, IACR Rothamsted, Harpenden, Herts AL5 2JQ, UK
}

\begin{abstract}
Changes in atmospheric composition affect plant quality and herbivore performance. We used the Aspen Free Air $\mathrm{CO}_{2}$ Enrichment (FACE) facility to investigate the impacts of elevated carbon dioxide $\left(\mathrm{CO}_{2}\right)$ and ozone $\left(\mathrm{O}_{3}\right)$ on the performance of the aphid Cepegillettea betulaefoliae Granovsky feeding on paper birch (Betula papyrifera Marsh.). In Year 1, we simultaneously measured individual performance and population growth rates, and in Year 2 we surveyed natural aphid, predator and parasitoid populations throughout the growing season. Aphid growth and development (relative growth rate (RGR), development time, adult weight, embryo number and the birth weight of newborn nymphs) were unaffected by $\mathrm{CO}_{2}$ and $\mathrm{O}_{3}$. Aphid fecundity decreased on trees grown at elevated $\mathrm{CO}_{2}, \mathrm{O}_{3}$ and $\mathrm{CO}_{2}+\mathrm{O}_{3}$. Neither nymphal performance nor adult size were reliable indicators of future fecundity at elevated $\mathrm{CO}_{2}$ and/or $\mathrm{O}_{3}$. Aphid populations protected from natural enemies were unaffected by elevated $\mathrm{CO}_{2}$, but increased significantly at elevated $\mathrm{O}_{3}$. Individual fecundity in elevated $\mathrm{CO}_{2}$ and $\mathrm{O}_{3}$ atmospheres did not predict population growth rates, probably because of changes in the strength of intraspecific competition or the ability of the aphids to induce nutrient sinks. Natural aphid, predator and parasitoids populations (Year 2) showed few significant responses to $\mathrm{CO}_{2}$ and $\mathrm{O}_{3}$, although $\mathrm{CO}_{2}$ and $\mathrm{O}_{3}$ did affect the timing of aphid and natural enemy peak abundance. Elevated $\mathrm{CO}_{2}$ and $\mathrm{O}_{3}$ affected aphid and natural enemy populations independently: no $\mathrm{CO}_{2} \times \mathrm{O}_{3}$ interactions were observed. We conclude that: (1) aphid individual performance did not predict population responses to $\mathrm{CO}_{2}$ and $\mathrm{O}_{3}$ and (2) elevated $\mathrm{CO}_{2}$ and $\mathrm{O}_{3}$ atmospheres are unlikely to affect $\mathrm{C}$. betulaefoliae populations in the presence of natural enemy communities.
\end{abstract}

Keywords: carbon dioxide, forests, global change, natural enemies, ozone, pests

Received 5 December 2002; revised version received 23 January 2003 and accepted 6 July 2003

\section{Introduction}

The increases in atmospheric carbon dioxide $\left(\mathrm{CO}_{2}\right)$ and ozone $\left(\mathrm{O}_{3}\right)$ concentrations predicted to occur in the next 50-100 years (IPCC, 2001) are likely to affect the nutritional ecology of herbivorous insects (Brown, 1995; Bezemer \& Jones, 1998). Since $\mathrm{CO}_{2}$ and $\mathrm{O}_{3}$ have strong and opposing effects on plant productivity (Makino \& Mae, 1999; Krupa et al., 2001) and may alter both the nutritional and defensive composition of plant tissues (reviewed in Kangasjärvi et al., 1994; Lindroth, 1996), both gases may change the availability and quality of resources for herbivorous insects. Elevated

Correspondence: Caroline S. Awmack, fax (001) 608262 3322, e-mail: awmack@entomology.wisc.edu
$\mathrm{CO}_{2}$ atmospheres reduce plant quality for most insect herbivores (reviewed in Bezemer \& Jones, 1998; Coviella \& Trumble, 1999), while elevated $\mathrm{O}_{3}$ has more complex effects (reviewed in Brown, 1995). The few studies that have investigated the interactive effects of $\mathrm{CO}_{2}$ and $\mathrm{O}_{3}$ found no evidence that $\mathrm{CO}_{2}$ modifies the effects of $\mathrm{O}_{3}$ on herbivore performance (Heagle, et al., 1994; Herms et al., 1995; Kopper et al., 2001; Kopper \& Lindroth, 2002), despite mounting evidence that $\mathrm{CO}_{2}$ reduces the negative impacts of $\mathrm{O}_{3}$ on plant productivity (Dickson et al., 1998; Donnelly et al., 2000).

Most investigations of herbivore responses to future global environmental change use short-term measures of growth and developmental rates or correlates of fecundity such as pupal or adult mass (Bezemer \& Jones, 1998) and assume that small adults will produce 
fewer offspring than large adults. However, changes in plant quality may affect size $\times$ fecundity relationships by altering the allocation of resources between somatic and reproductive tissues (reviewed in Leather, 1988; Awmack \& Leather, 2002). In many insect orders, changes in plant quality may affect the relationship between female size and the number of offspring produced (e.g., Homoptera (Wojciechowicz-Zytko \& van Emden, 1995), Orthoptera (Joern \& Behmer, 1998), Lepidoptera (Parry et al., 2001), Coleoptera (Berrigan, 1991) and Hymenoptera (Berrigan, 1991)). Because both $\mathrm{CO}_{2}$ and $\mathrm{O}_{3}$ affect plant quality, it may not be possible to make reliable predictions about the future fecundity of herbivorous insects without directly measuring the number of offspring produced. Similarly, recent studies (Bezemer et al., 1999; Percy et al., 2002) suggest that the performance of individual herbivores may not predict population responses to elevated $\mathrm{CO}_{2}$ or $\mathrm{O}_{3}$.

Aphids are a very useful model system for comparisons between individual and population responses to global change, since their biology is well understood (Dixon, 1998) and they develop rapidly and may have several generations in a single growing season. Several recent studies have investigated the independent effects of both $\mathrm{CO}_{2}$ (Salt et al., 1996; Docherty et al., 1997; Bezemer et al., 1998, 1999; Diaz et al., 1998; Awmack \& Harrington, 2000; Hughes \& Bazzaz, 2001) and $\mathrm{O}_{3}$ (Whittaker et al., 1989; Salt \& Whittaker, 1995) on aphid populations. We are not aware of any investigations linking the interacting effects of $\mathrm{CO}_{2}$ and $\mathrm{O}_{3}$ on the performance of individual herbivores to the performance of aphid populations.

Changes in the performance of individual insects may not predict population responses if other factors limiting population growth rates are also affected by changes in plant quality at elevated $\mathrm{CO}_{2}$ and/or $\mathrm{O}_{3}$. Changes in the strength of intraspecific competition may affect aphid population growth rates at elevated $\mathrm{CO}_{2}$ (Bezemer et al., 1999; Awmack \& Harrington, 2000). Natural enemy performance may also decrease (Roth \& Lindroth, 1995), increase (Stiling et al., 1999) or may be unaffected (Bezemer et al., 1998; Stacey \& Fellowes, 2002). We are not aware of any studies investigating the impacts of $\mathrm{O}_{3}$ on competition, but two studies (Gate et al., 1995; Dahlsten et al., 1997) found negative effects of $\mathrm{O}_{3}$ on natural enemy performance, and Holton (2001) showed that parasitoid performance in $\mathrm{CO}_{2}+\mathrm{O}_{3}$ enhanced atmospheres depended on host plant genotype.

Reliable predictions of the impacts of future global change on insect populations therefore require that we (1) understand changes in individual performance (2) can scale up individual performance to predict population responses, (3) understand the impacts of $\mathrm{CO}_{2}$ and
$\mathrm{O}_{3}$ on top-down regulation by natural enemies and (4) understand the consequences of interactions between the effects of $\mathrm{CO}_{2}$ and $\mathrm{O}_{3}$ on herbivore and natural enemy populations. No study has yet combined investigations of the impacts of $\mathrm{CO}_{2}$ or $\mathrm{O}_{3}$ on individual insects with studies of insect populations, and related the results to surveys of natural populations exposed to natural enemies. The development of Free Air $\mathrm{CO}_{2}$ Enrichment (FACE) facilities (Hendrey et al., 1993) has allowed natural invertebrate communities to be exposed to elevated $\mathrm{CO}_{2}$ (and in some cases, $\mathrm{O}_{3}$ ) atmospheres. However, although FACE facilities have been extensively used to investigate changes in plant communities (e.g. Garcia et al., 1998; Norby \& Cotrufo, 1998; Reich et al., 2001), only one study has investigated the impacts on higher trophic levels (Hansen et al., 2001). In this paper, we describe a set of experiments conducted at the Aspen FACE site in Wisconsin, USA (Dickson et al., 2000) to investigate the independent and interacting effects of elevated $\mathrm{CO}_{2}$ and $\mathrm{O}_{3}$ on the performance of the aphid Cepegillettea betulaefoliae Granovsky reared on paper birch (Betula papyrifera Marsh.). At the individual scale (Study 1), we investigated the effects of $\mathrm{CO}_{2}$ and $\mathrm{O}_{3}$ on aphid growth and developmental rates, adult weight, embryo number and the cumulative fecundity of adult aphids. We compared these data with a simultaneous investigation of the effects of elevated $\mathrm{CO}_{2}$ and $\mathrm{O}_{3}$ on aphid populations, using aphids protected from natural enemies with mesh sleeves (Study 2), and, the following year, with a survey of natural aphid, predator and parasitoid populations (Study 3).

\section{Materials and methods}

\section{Site description}

The Aspen FACE site, situated in Harshaw, Wisconsin (45.6 lat., $89.5^{\circ}$ long., Dickson et al., 2000) consists of twelve $30 \mathrm{~m}$ diameter FACE rings arranged in a fully replicated and blocked factorial design, with two levels of $\mathrm{CO}_{2}$ and two levels of $\mathrm{O}_{3}$. Three rings receive ambient air ('Control' i.e. ambient $\mathrm{CO}_{2}$ and $\mathrm{O}_{3}$ ), three rings receive elevated $\mathrm{CO}_{2} \quad\left(\mathrm{CO}_{2}{ }^{\prime}=570 \mathrm{ppm} \mathrm{CO}_{2}\right.$, equivalent to ambient $+200 \mathrm{ppm}$ ), three rings receive an average of 50-60 $\mathrm{ppb} \mathrm{O}_{3}$ (approximately 1.5 times the background ambient levels of $30-40 \mathrm{ppb}_{3}$ ) and the final three rings receive $570 \mathrm{ppm} \mathrm{CO} 2$ and $50-60 \mathrm{ppb}$ $\mathrm{O}_{3} . \mathrm{CO}_{2}$ and $\mathrm{O}_{3}$ are released during daylight hours. $\mathrm{O}_{3}$ is not released during fog or rain events, since natural $\mathrm{O}_{3}$ production normally occurs as a result of photochemical reactions in the troposphere. $\mathrm{O}_{3}$ fumigation follows a dynamic profile, established from a moderately polluted city (Leelenaw, Michigan, USA) and 
varies according to the prevailing climatic conditions (Dickson et al., 2000). Each FACE ring was planted with trembling aspen (Populus tremuloides Michx.), sugar maple (Acer saccharum Marsh.) and paper birch (Betula papyrifera Marsh.) in 1997. $\mathrm{CO}_{2}$ and $\mathrm{O}_{3}$ exposure commenced in 1998. These experiments were carried out during the 1999 and 2000 growing seasons when the trees were between two and four metres tall. All the studies described below used the same seven trees in each FACE ring to estimate the variation in aphid performance within each ring, although 'ring' was used as the replicate in all statistical analyses.

\section{Insect rearing}

All three studies used aphids from trees in the FACE rings (i.e. aphids that had developed at ambient or elevated $\mathrm{CO}_{2}$ and/or $\mathrm{O}_{3}$ ). No aphids were moved between FACE rings. The first two studies used aphids from cultures (initiated using wingless fourth instar aphids that had developed in each FACE ring) maintained on a newly expanded birch shoot in each ring and protected from natural enemies with mesh sleeves ( $45 \mathrm{~cm}$ length $\times 45 \mathrm{~cm}$ width). Since the development of aphid embryos begins in the ovarioles of their grandmothers (Dixon, 1998), these two studies used the grand-daughters of these initial aphids, ensuring that the aphids used had spent their entire development in the appropriate $\mathrm{CO}_{2}$ and/or $\mathrm{O}_{3}$ treatment. The third study surveyed natural aphid infestations throughout the growing season and did not use aphids from cultures.

\section{Study 1. Measurement of individual performance}

In each ring, seven groups of five $24 \mathrm{~h}$ old 1 st instar nymphs (84 in total, the progeny of wingless adult aphids from the cultures described above) were used to investigate the impacts of elevated $\mathrm{CO}_{2}$ and/or $\mathrm{O}_{3}$ on aphid performance. The average birth weight of each group of five aphids was measured to the nearest microgram using a Mettler Toledo MT5 microbalance (Mettler, Columbus, Ohio, USA). Each group of aphids was then confined to the underside of the youngest fully expanded leaf on the youngest south-facing branch of each of seven trees, mimicking the location of natural aphid populations (C. S. Awmack, unpublished results). Aphids were attached to the leaves using light foambased clip cages (Awmack, 1997) modified from MacGillivray \& Anderson (1957), which allowed maximum air circulation and caused minimal damage to the leaf surface (no marks were visible when the cage was removed from the leaf). These groups of aphids remained on the same branch throughout the experiment and were moved to new leaves as they became available, as birch exhibits indeterminate growth and natural aphid populations move to new leaves throughout the growing season (C. S. Awmack, personal observation). The aphids were observed daily until the final adult moult, when they were re-weighed to calculate the relative growth rate (Radford, 1967) (an estimate of the aphids' ability to convert phloem sap to biomass) using the formula RGR (relative growth rate) $=[\ln (W 2)-\ln (W 1)] / D$, where $W 1=$ birth weight, $W 2=$ final weight (both in micrograms) and $D=$ development time (the number of days from birth to the final adult moult).

One randomly selected adult from each clip cage was then dissected and the number of mature embryos (those with red eye pigments) was counted under a dissecting microscope at $\times 5$ magnification to determine potential fecundity (Traicevski \& Ward, 2002). A second randomly selected individual from each group was returned to each tree (again, to a new leaf on the same shoot) and was used to determine total fecundity (the total number of nymphs produced by the adult). All nymphs produced by this adult were counted and removed every $24 \mathrm{~h}$ to prevent any negative effects of crowding on fecundity. The clip cages were moved to the next new leaf on the branch every $4-5$ days. The average birth weight of each nymph was calculated by removing and weighing all the nymphs produced during the second $24 \mathrm{~h}$ of reproduction.

\section{Study 2: Aphid population responses to elevated $\mathrm{CO}_{2}$ and $\mathrm{O}_{3}$}

The investigation of aphid population growth rates (Study 2) commenced two days after Study 1, and used the same seven trees in each FACE ring. Groups of five $24 \mathrm{~h}$ old aphids were added to the three youngest leaves and the terminal bud of the branch nearest the branch used in Study 1. Each shoot was thoroughly searched before the aphids were added, and all aphids, predators, parasitoids, eggs, etc. were removed. The aphid populations were protected from natural enemies using fine mesh sleeves (approximately $45 \mathrm{~cm}$ length $\times 45 \mathrm{~cm}$ width). After 28 days (approximately twice the development time of $C$. betulaefoliae, and coincident with the final measurements of individual aphid performance in Study 1), all aphids were removed from the sleeves and counted.

Study 3: Responses of aphid communities to elevated $\mathrm{CO}_{2}$ and $\mathrm{O}_{3}$

Study 3 consisted of a survey of the naturally occurring aphid populations, and investigated the effects of elevated $\mathrm{CO}_{2}$ and $\mathrm{O}_{3}$ on aphids exposed to the 
predators and parasitoids inhabiting the FACE rings. A preliminary study (carried out in 1999) using trees that were not used for the measurement of individual performance showed that aphids and natural enemies were found only on the terminal shoots of the upper branches (C. S. Awmack, 1999 unpublished results). As only 7 birch trees in each FACE ring were available for entomological studies, surveys of natural populations were postponed until the following year (2000). This survey, conducted 13 times throughout the growing season, used one upper branch on each tree. The number of aphids and natural enemies (predominantly predators such as lacewings and ladybird beetles and parasitic Hymenoptera) on the terminal five short shoots on each branch were noted every 7-10 days from mid-June (when the first aphids were observed) until leaf fall at the end of September. The natural enemy data consisted of sightings of adult insects (particularly lacewings and ladybirds) and counts of egg masses produced by predators (particularly ladybirds, stinkbugs and lacewings). These egg masses were counted as ' 1 ' regardless of the number of eggs, because they represented a single visit by a predator. Parasitized aphid 'mummies' were included in the natural enemy counts and not the aphid counts. Eggs that had hatched and parasitized aphids from which the adult parasitoid had emerged were ignored on subsequent sampling dates.

\section{Data analysis}

As FACE studies generally have low numbers of true replicates (e.g. $N=3$ for each fumigation treatment at Aspen FACE), some authors have argued that data should be presented as significant if $P<0.1$ (Filion et al., 2000) to avoid Type II errors. In this paper, we will use the traditional value of alpha $(P<0.05)$ to determine significance, but we present exact $P$ values throughout the text, and describe $P$ values between 0.05 and 0.1 as marginally significant.

All data were analysed using analyses of variance in Procedure 'Mixed' in SAS (Littell et al., 1996). Because Aspen FACE incorporates a $2 \times 2$ factorial experiment (2 levels each of $\mathrm{CO}_{2}$ and $\mathrm{O}_{3}$ ), the statistical model used $\mathrm{CO}_{2}$ and $\mathrm{O}_{3}$ as fixed treatment effects, with the three blocks and tree(block) as random effects.

The effects of elevated $\mathrm{CO}_{2}$ and $\mathrm{O}_{3}$ on the performance of individual aphids were analyzed using separate ANOVAs for each fitness parameter. The effects of elevated $\mathrm{CO}_{2}$ and $\mathrm{O}_{3}$ on aphid populations protected from natural enemies (Study 2), and on the abundance of natural aphid populations (Study 3) were analysed after the data had been $\log 10(N+1)$ transformed to normalize variance. Because natural enemy abundance was generally low, all natural enemies were grouped into a single category ('Natural enemies') rather than being analysed separately as 'predators', 'parasitoids', etc. The data from Study 2 were analysed using the model described above, while the data from Study 3 used a repeated measures ANOVA, with time (year) as the repeated measures term. The latter model also used a spatial (power) term, which fits a timeseries covariance structure in which the correlations decline as a function of time, and takes into account the fact that the time intervals between sampling dates are not necessarily equal. This term also corrects for any autocorrelation among sampling dates (Littell et al., 1996).

\section{Results}

\section{Study 1. Measurement of individual performance}

Elevated $\mathrm{CO}_{2}$ and $\mathrm{O}_{3}$ did not significantly affect the growth and developmental rates of individual $C$. betulaefoliae (Table 1, Fig. 1). The RGR of aphids reared at elevated $\mathrm{CO}_{2}$ and/or $\mathrm{O}_{3}$ did not differ from the control aphids (Fig. 1a), while aphid development times showed a small (and only marginally significant) increase at elevated $\mathrm{CO}_{2}$, but not at elevated $\mathrm{O}_{3}$ (Fig. 1b). Elevated $\mathrm{CO}_{2}$ and $\mathrm{O}_{3}$ did not affect the reproductive fitness of individual aphids as neither adult weight nor potential fecundity (embryo number) were significantly affected (Fig. 1c and d). $\mathrm{CO}_{2}$ and $\mathrm{O}_{3}$ had no effect on the allocation of resources to the next-generation nymphs, since the birth weight of the nymphs produced by these adults (G2 weight) was unaffected (mean birth weight $(\mu \mathrm{g}), \pm \mathrm{SE}$ ): control (109 \pm 17$), \mathrm{CO}_{2}$ $(95 \pm 19), \mathrm{O}_{3}(119 \pm 14)$ and $\mathrm{CO}_{2}+\mathrm{O}_{3}(129 \pm 23)$.

The fecundity (Fig. 2) of the individual aphids did not reflect either their adult weight or the number of embryos in their reproductive tract (Fig. 1c and d), since elevated $\mathrm{CO}_{2}$ and $\mathrm{O}_{3}$ had strong negative effects on the cumulative fecundity of $C$. betulaefoliae. The decrease in reproductive rates became more apparent towards the end of the adult's reproductive life, suggesting that females were unable to maintain embryo maturation throughout their lifetime. The fecundity of similarly sized aphids therefore differed according to the $\mathrm{CO}_{2}$ or $\mathrm{O}_{3}$ treatment that they experienced during their development.

Study 2: Aphid population responses to elevated $\mathrm{CO}_{2}$ and $\mathrm{O}_{3}$

Aphid populations protected from natural enemies using mesh sleeves did not show the same responses to $\mathrm{CO}_{2}$ and $\mathrm{O}_{3}$ as did individual aphids (Fig. 3). 
Table 1 Results of analysis of variance ( $F$ and $P$ values) of the impacts of elevated $\mathrm{CO}_{2}$ and $\mathrm{O}_{3}$ atmospheres on performance of the aphid Cepegillettea betulaefoliae

\begin{tabular}{|c|c|c|c|c|c|c|c|c|c|c|}
\hline \multirow[b]{2}{*}{ Treatment } & \multicolumn{2}{|l|}{ RGR } & \multicolumn{2}{|c|}{ Adult weight } & \multicolumn{2}{|c|}{$\begin{array}{l}\text { Development } \\
\text { time }\end{array}$} & \multicolumn{2}{|c|}{ Embryo number } & \multicolumn{2}{|c|}{ G2 weight } \\
\hline & $F_{1,4}$ & $P$ & $F_{1,4}$ & $P$ & $F_{1,6}$ & $P$ & $F_{1,4}$ & $P$ & $F_{1,4}$ & $P$ \\
\hline $\mathrm{CO}_{2}$ & 0.52 & 0.512 & 0.30 & 0.612 & 4.24 & 0.085 & 0.10 & 0.769 & 0.01 & 0.935 \\
\hline $\mathrm{O}_{3}$ & 0.39 & 0.624 & 0.03 & 0.877 & 0.10 & 0.760 & 0.37 & 0.576 & 1.40 & 0.301 \\
\hline $\mathrm{CO}_{2} \times \mathrm{O}_{3}$ & 0.67 & 0.462 & 0.10 & 0.773 & 0.04 & 0.851 & 0.01 & 0.939 & 0.41 & 0.556 \\
\hline
\end{tabular}

See Materials and methods for a detailed description of the model used in the analysis and Fig. 1 for a graphical representation of the data.

MRGR, mean relative growth rate; RGR, relative growth rate; G2 weight, average birth weight of nymphs produced by the adults.

(a)

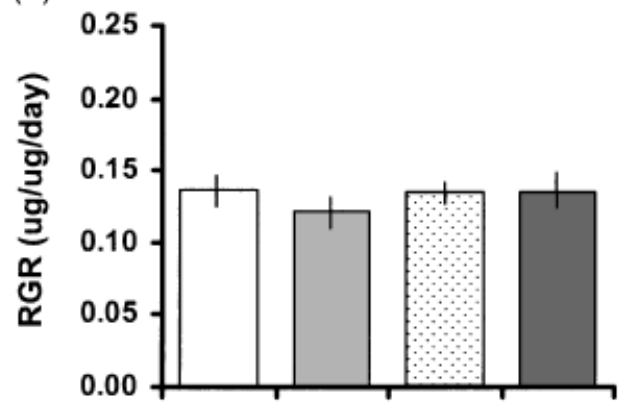

(c)

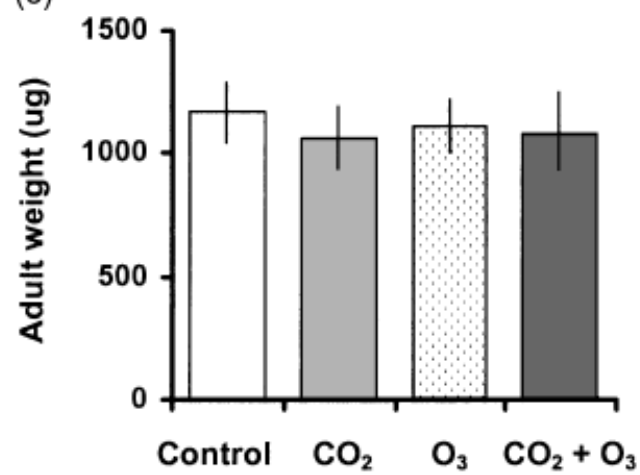

(b)

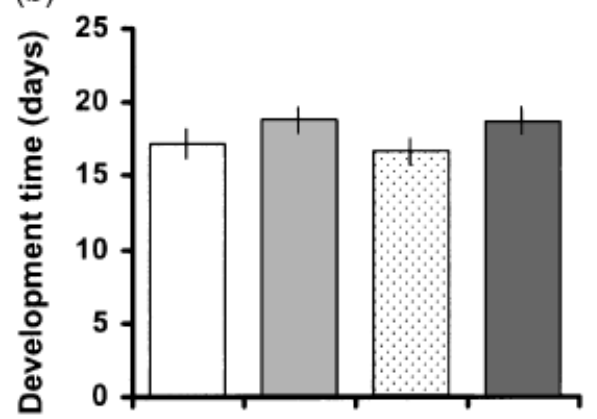

(d)

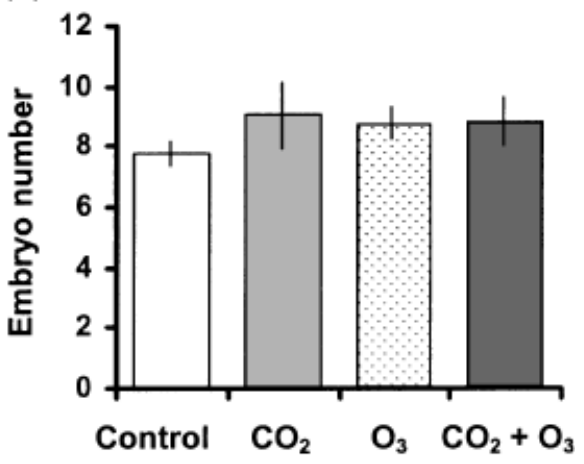

Fig. 1 Performance of individual Cepegillettea betulaefoliae reared on Betula papyrifera at the Aspen FACE site. Control = ambient $\mathrm{CO}_{2}$, ambient $\mathrm{O}_{3}, \mathrm{CO}_{2}$ = elevated $(570 \mathrm{ppm}) \mathrm{CO}_{2}$, ambient $\mathrm{O}_{3}, \mathrm{O}_{3}$ = elevated $(1.5 \times$ ambient $) \mathrm{O}_{3}$, ambient $\mathrm{CO}_{2}, \mathrm{CO}_{2}+\mathrm{O}_{3}=$ elevated $\mathrm{CO}_{2}$, elevated $\mathrm{O}_{3}$. (a) relative growth rate, (b) development time, (c) adult weight and (d) embryo number (potential fecundity). All data are shown \pm 1 SEM and are the means of data from three replicate FACE rings.

Population responses did not reflect individual growth and developmental parameters (Fig. 1) or individual fecundity (Fig. 2). Aphid populations were marginally significantly smaller at elevated $\mathrm{CO}_{2} \quad\left(F_{1,6}=4.66\right.$, $P=0.074)$, but increased at elevated $\mathrm{O}_{3}\left(F_{1,6}=11.86\right.$, $P=0.014)$. Elevated $\mathrm{CO}_{2}$ did not modify the impacts of elevated $\mathrm{O}_{3}$ on aphid populations (i.e. no significant $\mathrm{CO}_{2}{ }^{*} \mathrm{O}_{3}$ interaction: $\left.F_{1,6}=0.81, P=0.403\right)$.
Study 3: Aphid community responses to elevated $\mathrm{CO}_{2}$ and $\mathrm{O}_{3}$

The effects of elevated $\mathrm{CO}_{2}$ and $\mathrm{O}_{3}$ on communities of aphids and their natural enemies were more complex when populations were followed throughout the growing season the following year (Fig. 4). Aphid and natural enemy abundance both varied throughout the 
growing season (significant time (year) interaction: aphids, $F_{12,960}=40.97, P=<0.0001$, natural enemies, $\left.F_{12,960}=3.50, P<0.0001\right)$. Aphid abundance was sig-

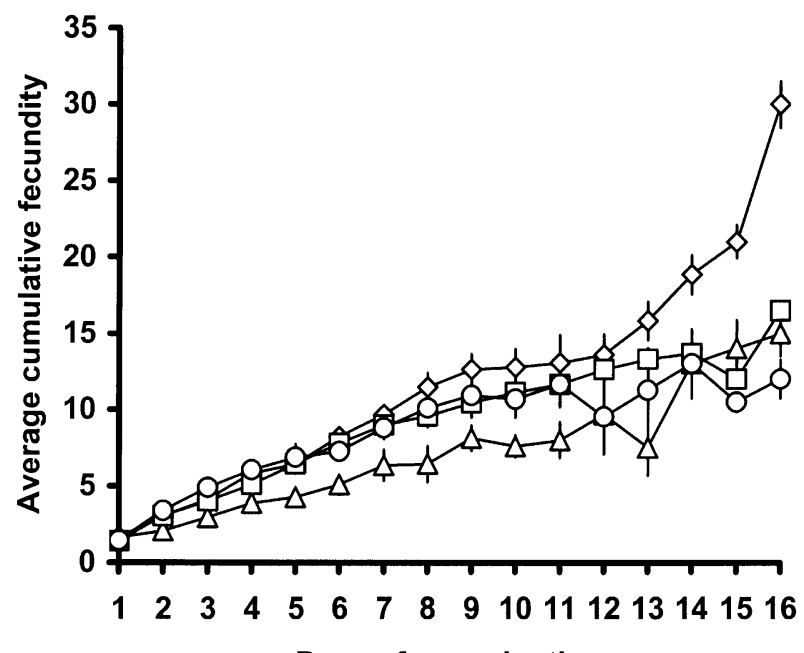

Days of reproduction

$$
\checkmark \text { Control } \triangle-\mathrm{CO}_{2}-\square-\mathrm{O}_{3}-\mathrm{O}-\mathrm{CO}_{2}+\mathrm{O}_{3}
$$

Fig. 2 Average cumulative fecundity of Cepegillettea betulaefoliae reared on Betula papyrifera at the Aspen FACE site. Control = ambient $\mathrm{CO}_{2}$, ambient $\mathrm{O}_{3}, \mathrm{CO}_{2}=$ elevated $(570 \mathrm{ppm})$ $\mathrm{CO}_{2}$, ambient $\mathrm{O}_{3}, \mathrm{O}_{3}=$ elevated $(1.5 \times$ ambient $) \mathrm{O}_{3}$, ambient $\mathrm{CO}_{2}, \mathrm{CO}_{2}+\mathrm{O}_{3}=$ elevated $\mathrm{CO}_{2}$, elevated $\mathrm{O}_{3}$. All data are shown \pm 1 SEM and are the means of three replicate FACE rings. Average fecundity declined at elevated $\mathrm{CO}_{2}$ on day 13 because a female with a particularly high reproductive rate died, reducing the average for the entire replicate.

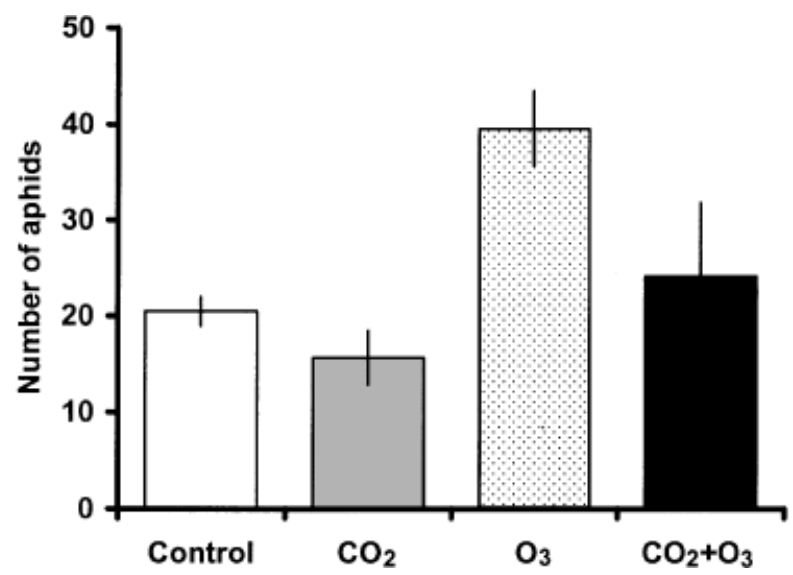

Fig. 3 Final populations of Cepgillettea betulaefoliae reared for 28 days on Betula papyrifera at the Aspen FACE site. All replicates initially contained five 1st instar aphids, protected from natural enemies with mesh bags. Control $=$ ambient $\mathrm{CO}_{2}$, ambient $\mathrm{O}_{3}$, $\mathrm{CO}_{2}=$ elevated $(570 \mathrm{ppm}) \mathrm{CO}_{2}$, ambient $\mathrm{O}_{3}, \mathrm{O}_{3}=$ elevated $(1.5 \times$ ambient $) \mathrm{O}_{3}$, ambient $\mathrm{CO}_{2}, \mathrm{CO}_{2}+\mathrm{O}_{3}=$ elevated $\mathrm{CO}_{2}$, elevated $\mathrm{O}_{3}$. All data are shown \pm 1 SEM and are the means of three replicate FACE rings. nificantly affected by elevated $\mathrm{CO}_{2}$ on some sampling dates towards the end of the growing season (significant $\mathrm{CO}_{2} \times$ date interaction, $\left.F_{12}, 960=1.88, P=0.033\right)$. Elevated $\mathrm{O}_{3}$ alone did not modify aphid abundance $\left(\mathrm{O}_{3}\right.$ main effect: $F_{1,6}=1.50, P=0.267$ ) but on some sampling

Aphids

$(-0-)$

Natural enemies
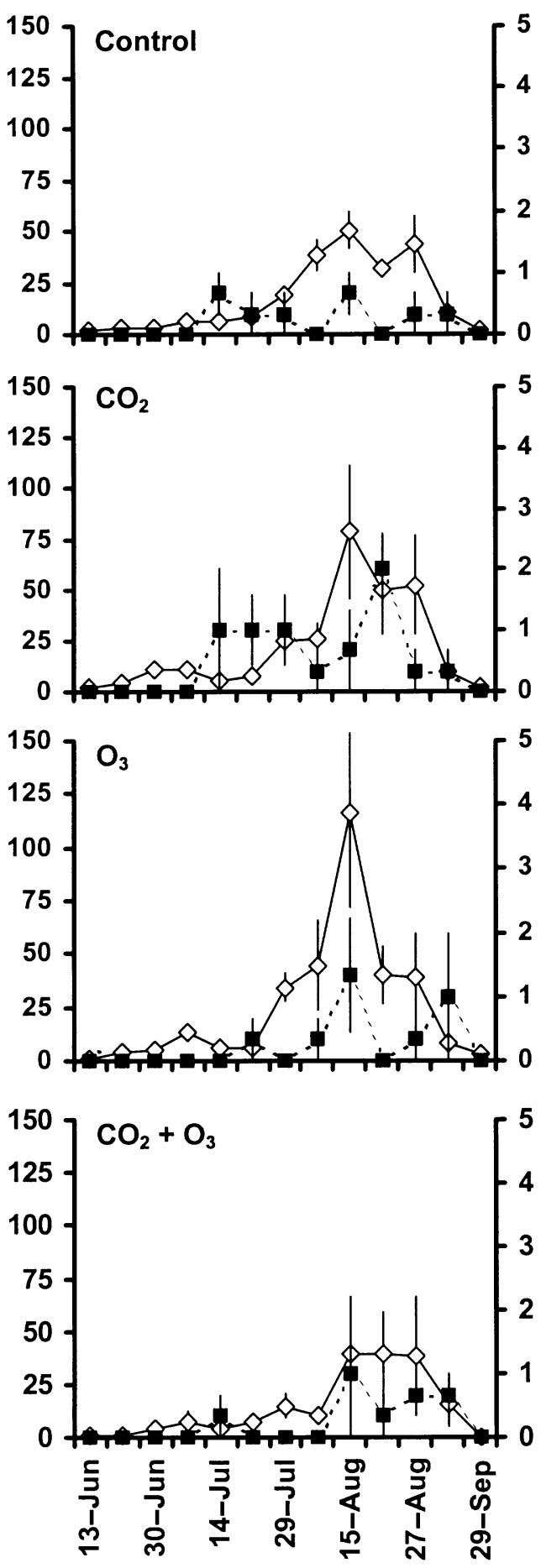
dates, elevated $\mathrm{O}_{3}$ modified the effects of elevated $\mathrm{CO}_{2}$ on aphid abundance (significant $\mathrm{CO}_{2} \times \mathrm{O}_{3} \times$ date interaction $\left.F_{12,960}=2.13, P=0.013\right)$. Natural enemy abundance increased under elevated $\mathrm{CO}_{2}$, but only on one sampling date towards the end of the growing season $\left(F_{1,6}=6.91, P=0.039\right)$. Natural enemy abundance was unaffected by elevated $\mathrm{O}_{3} \quad\left(F_{1,6}=1.51\right.$, $P=0.265)$.

\section{Discussion}

These data represent the first investigation of the longterm effects of elevated $\mathrm{CO}_{2}$ and $\mathrm{O}_{3}$ atmospheres on natural insect herbivore populations. The aphids used in this study were exposed to the most 'realistic' simulation of future elevated $\mathrm{CO}_{2}$ and $\mathrm{O}_{3}$ atmospheres currently possible. At the individual scale, elevated $\mathrm{CO}_{2}$ and $\mathrm{O}_{3}$ did not significantly affect growth rates, potential fecundity (embryo number) or offspring quality (Fig. 1, Table 1), but the cumulative fecundity of aphids was lower than that of aphids reared on the control trees (Fig. 2). The population-scale study (Study 2) showed that elevated $\mathrm{CO}_{2}$ did not significantly affect aphid populations, while elevated $\mathrm{O}_{3}$ had a strong positive effect. The surveys of aphid and natural enemy communities (Study 3) revealed complex time-dependent interactions with elevated $\mathrm{CO}_{2}$ and no effects of elevated $\mathrm{O}_{3}$. The data suggest firstly, that $\mathrm{CO}_{2}$ and $\mathrm{O}_{3}$ had few interacting effects on $C$. betulaefoliae, and secondly, that measures of individual fecundity did not predict population responses, and population responses did not predict community responses.

Previous studies show that the responses of other aphid species to elevated $\mathrm{CO}_{2}$ or $\mathrm{O}_{3}$ are also complex. Tree-feeding aphids show few significant responses to elevated $\mathrm{CO}_{2}$ (Docherty et al., 1997), while crop-feeding species may respond positively (Awmack et al., 1997; Bezemer et al., 1998; Hughes and Bazzaz 2001; Zhang et al., 2001; Stacey \& Fellowes, 2002), negatively (Newman et al., 1999) or not at all (Hughes \& Bazzaz, 2001), and the same species may show different responses on different host plant species (Awmack et al., 1997; Bezemer et al., 1999). Aphid responses to $\mathrm{O}_{3}$ also depend on the aphid and host plant species (Brown,

Fig. 4 Populations of aphids and natural enemies on Betula papyrifera at the Aspen FACE site $(N=1$ tree per ring). The natural enemies were predominantly predators and parasitoids. Control = ambient $\mathrm{CO}_{2}$, ambient $\mathrm{O}_{3}, \mathrm{CO}_{2}=$ elevated (570 ppm) $\mathrm{CO}_{2}$, ambient $\mathrm{O}_{3}, \mathrm{O}_{3}=$ elevated $(1.5 \times$ ambient $) \mathrm{O}_{3}$, ambient $\mathrm{CO}_{2}, \mathrm{CO}_{2}+\mathrm{O}_{3}=$ elevated $\mathrm{CO}_{2}$, elevated $\mathrm{O}_{3}$. All data are shown \pm 1 SEM and are the means of three replicate FACE rings. Since natural enemy abundance was low, all data were pooled prior to analysis.
1995; Holopainen et al., 1995), plant phenology (Holopainen \& Kössi, 1998), soil nutrient availability (Kainulainen et al., 2000) and the duration of exposure (Brown et al., 1992). Cepegillettea betulaefoliae performance on paper birch therefore does not confirm any general trends, since aphids, like many other species (Lawton, 2000), show idiosyncratic responses to elevated $\mathrm{CO}_{2}$ and $\mathrm{O}_{3}$.

The poor correlation between individual and population growth rates is intriguing. The growth, development, adult weight and potential fecundity of individual aphids was unaffected by elevated $\mathrm{CO}_{2}$ or $\mathrm{O}_{3}$ (Fig. 1). Size was not, therefore, a reliable predictor of future fecundity. As the newly moulted adults contained similar numbers of mature embryos (Fig. 1f), changes in resource allocation within the developing aphid (perhaps associated with nutrient stress (e.g. Brough \& Dixon, 1990) do not explain these results. Aphids reared at elevated $\mathrm{CO}_{2}$ and/or $\mathrm{O}_{3}$ may either have been unable to maintain embryo maturation once their initial complement of mature embryos were born, or have resorbed the youngest undifferentiated embryos in response to low host plant quality (e.g. Ward \& Dixon, 1982; Sequeira \& Dixon, 1996). The decline in $C$. betulaefoliae reproductive output at elevated $\mathrm{CO}_{2}$ and $\mathrm{O}_{3}$ may therefore be related to either an inability to maintain embryo maturation or to the resorption of embryos to maintain adult survival. If these data reflect a more general trend (i.e. that adult weight and/or embryo number do not reflect future fecundity), studies that have used adult weight as a correlate of fecundity to predict the responses of other herbivore species to elevated $\mathrm{CO}_{2}$ and $\mathrm{O}_{3}$ atmospheres (reviewed in Brown, 1995; Bezemer \& Jones, 1998) may be misleading.

Previous studies of the nutritional quality of the birch trees used in this study show that the trees grown at elevated $\mathrm{CO}_{2}, \mathrm{O}_{3}$ and $\mathrm{CO}_{2}+\mathrm{O}_{3}$ had reduced tissue nitrogen concentrations compared with the control trees (Kopper et al., 2001). In this study, individual fecundity was therefore correlated with tissue nitrogen concentrations, although aphid population responses to $\mathrm{CO}_{2}$ and $\mathrm{O}_{3}$ (Fig. 3) were not. The reduced nutritional quality of these trees therefore did not explain the difference between the individual- and populationscale responses of $C$. betulaefoliae to elevated $\mathrm{CO}_{2}$ and $\mathrm{O}_{3}$. Because all the aphids used had been reared in the appropriate environment for at least three generations prior to the study, maternal effects from ambient- $\mathrm{CO}_{2}$ and $-\mathrm{O}_{3}$ environments can probably be ruled out. Docherty et al. (1997) also found that aphid performance at elevated $\mathrm{CO}_{2}$ did not correlate with leaf amino acid concentrations, although Kainulainen et al. (2000) found a positive correlation between aphid performance and amino acid availability at elevated $\mathrm{O}_{3}$. 
Some aphid species perform better when they are reared in large aggregations (Eichorn, 1968; Way \& Cammell, 1970; Dixon \& Wratten, 1971) since they can induce nutrient sinks more effectively than aphids reared individually. Studies investigating the induction of sinks in free-living aphids (e.g. Way \& Cammell, 1970) suggest that the benefits of aggregation only occur during the early stages of aphid population growth: after this, intraspecific competition due to crowding may reduce population growth rates. We suggest that short-term changes in either the ability of the aphids to induce nutrient sinks or the strength of intraspecific competition explain the differences between individual and population performance in this study. The surveys of natural populations (Study 3) may not have detected these responses because of competition with other herbivores (which were excluded in Studies 1 \& 2), changes in natural enemy performance (rather than abundance) or differences in weather conditions between the two sampling years.

The low natural enemy densities observed in this system (Fig. 4) suggest that the strength of top-down regulation during this study was weak, relative to the impacts of $\mathrm{CO}_{2}$ and $\mathrm{O}_{3}$ on plant quality. Since $C$. betulaefoliae does not have an alternative host in the vicinity of the FACE site and more than $99 \%$ of the aphids encountered in the population surveys were wingless (C. S. Awmack, personal observation), the aphid populations in this study are unlikely to have been affected by immigration or emigration. The natural enemies, however, are more mobile and exploit aphid populations on the other plant species in the FACE rings (C. S. Awmack, personal observation). In contrast to the data presented here, similar natural enemy populations on the aspen trees inter-planted with the birch trees used in this study exhibited strong positive responses to elevated $\mathrm{CO}_{2}$ and negative responses to elevated $\mathrm{O}_{3}$ (Percy et al., 2002). The effects of elevated $\mathrm{CO}_{2}$ and $\mathrm{O}_{3}$ on the population dynamics of aphids and their natural enemies may therefore be influenced by both the aphid and plant species, even among species in the same ecosystem. Further studies are planned to investigate the abundance of insect herbivores and their natural enemies on a wider range of host plants within the FACE rings, and to investigate changes in the performance (rather than abundance) of the natural enemies in this system.

We conclude that the performance of $C$. betulaefoliae at elevated $\mathrm{CO}_{2}$ and $\mathrm{O}_{3}$ depended on whether the aphids were reared as individuals or in populations and hence that individual-based studies may not be reliable indicators of population responses to $\mathrm{CO}_{2}$ or $\mathrm{O}_{3}$. Scaling up data collected using individuals to predict the population responses of other herbivorous insects to
$\mathrm{CO}_{2}$ and $\mathrm{O}_{3}$ may be problematic, as growth and developmental rates did not predict fecundity, and fecundity did not predict population growth. We found little evidence that elevated $\mathrm{CO}_{2}$ modifies the impacts of elevated $\mathrm{O}_{3}$ on aphid performance, despite the evidence that elevated $\mathrm{CO}_{2}$ atmospheres reduce the damaging effects of $\mathrm{O}_{3}$ on tree productivity at this site (Dickson et al., 1998). The responses of this aphid species to $\mathrm{CO}_{2}$ and $\mathrm{O}_{3}$ appear to be driven by changes in plant quality and the strength of intraspecific competition, and not by changes in the strength of top-down regulation, since natural enemy abundance showed few responses to $\mathrm{CO}_{2}$ or $\mathrm{O}_{3}$. Other herbivores, particularly those exploiting fast-growing host plants such as agricultural crops, may differ in their responses to $\mathrm{CO}_{2}$ and $\mathrm{O}_{3}$ : a wider range of species needs to be investigated before generalizations can be made about the impacts of elevated $\mathrm{CO}_{2}$ and $\mathrm{O}_{3}$ on all aphid and natural enemy populations.

\section{Acknowledgements}

This work was funded by a Small Ecological Project Grant from the British Ecological Society (number 1682), a Natural Environment Research Council ROPA award (number GR3/R9675), the National Science Foundation of the USA (grant DEB-9707263), the U.S. Department of Agriculture (NRICGP grant number 0002982) and the U.S. Department of Energy (OBER grant DE-FG0298ER62680). The Aspen FACE site is principally supported by the Office of Science (BER), U.S. Department of Energy (grant DE-FG02-95ER62125) the U.S. Forest Service Northern Global Change Program and North Central Research Station, Michigan Technological University, and Natural Resources Canada Canadian Forest Service.

We thank David Voegtlin at the Illinois Natural History Survey, Champaign, Illinois for identifying the aphid species used in this study. We also acknowledge Sarah Wood, Aimee Weldon and Heidi Barnhill for their excellent practical assistance throughout this project, Rick Nordheim and Peter Crump for statistical advice and two anonymous referees for their comments on an earlier draft of this manuscript. We gratefully acknowledge the technical assistance of Jaak Sober and the Aspen-FACE team for the control and maintenance of the FACE site. IACR Rothamsted receives grant-aided support from the Biotechnology and Biological Sciences Research Council of the United Kingdom.

\section{References}

Awmack CS (1997) Aphid-plant interactions at ambient and elevated $\mathrm{CO}_{2}$. PhD thesis, Imperial College, London.

Awmack CS, Harrington R (2000) Elevated $\mathrm{CO}_{2}$ affects the interactions between aphid pests and host plant flowering. Agricultural and Forest Entomology, 2, 57-61.

Awmack CS, Harrington R, Leather SR (1997) Host plant effects on the performance of the aphid Aulacorthum solani (Homoptera: Aphididae) at ambient and elevated $\mathrm{CO}_{2}$. Global Change Biology, 3, 545-549. 
Awmack CS, Leather SR (2002) Host plant quality and fecundity in herbivorous insects. Annual Review of Entomology, 47, 817-844.

Berrigan D (1991) The allometry of egg size and number in insects. Oikos, 60, 313-321.

Bezemer TM, Jones TH (1998) Plant-insect herbivore interactions in elevated atmospheric $\mathrm{CO}_{2}$ : quantitative analyses and guild effects. Oikos, 82, 212-222.

Bezemer TM, Jones TH, Knight KJ (1998) Long-term effects of elevated $\mathrm{CO}_{2}$ and temperature on populations of the peach potato aphid Myzus persicae and its parasitoid Aphidius matricariae. Oecologia, 116, 128-135.

Bezemer TM, Knight KJ, Newington JE et al. (1999) How general are aphid responses to elevated atmospheric $\mathrm{CO}_{2}$ ? Annals of the Entomological Society of America, 92, 724-730.

Brough C, Dixon A (1990) The effects of starvation on the development and reproductive potential of aptertous virginoperae of vetch aphid Megoura viciae. Entomologia Experimentalis et Applicata, 55, 41-46.

Brown VC (1995) Insect herbivores and gaseous air pollutants current knowledge and predictions. In: Insects In a Changing Environment (eds Harrington R, Stork NE), pp. 219-249. Academic Press, New York.

Brown VC, McNeill S, Ashmore MR (1992) The effects of ozone fumigation on the performance of the black bean aphid, Aphis fabae Scop., feeding on broad beans, Vicia faba L. Agriculture, Ecosystems and Environment, 8, 71-78.

Coviella CE, Trumble JT (1999) Effects of elevated atmospheric carbon dioxide on insect-plant interactions. Conservation Biology, 13, 700-712.

Dahlsten DL, Rowney DL, Kickert RN (1997) Effects of oxidant air pollutants on Western Pine beetle (Coleoptera: Scolytidae) populations in Southern California. Environmental Pollution, 96, 415-423.

Diaz S, Fraser LH, Grime JP et al. (1998) The impact of elevated $\mathrm{CO}_{2}$ on plant-herbivore interactions: experimental evidence of moderating effects at the community level. Oecologia, 117, 177-186.

Dickson RE, Coleman MD, Riemenschneider DE et al. (1998) Growth of five hybrid poplar genotypes exposed to interacting elevated $\mathrm{CO}_{2}$ and $\mathrm{O}_{3}$. Canadian Journal of Forest Research, 28, 1706-1716.

Dickson RE, Lewin KF, Isebrands JG et al. (2000) Forest Atmosphere Carbon Transfer and Storage - II (FACTS II) - The Aspen Free-air $\mathrm{CO}_{2}$ and $\mathrm{O}_{3}$ Enrichment (FACE) Project: an overview. United States Department of Agriculture Forest Service North Central Research Station General Technical Report, NC-214.

Dixon AFG (1998) Aphid Ecology. Chapman and Hall, London.

Dixon AFG, Wratten SD (1971) Laboratory studies on aggregation, size and fecundity in the black bean aphid, Aphis fabae Scop. Bulletin of Entomological Research, 61, 97-111.

Docherty M, Wade FA, Hurst DK et al. (1997) Responses of tree sap-feeding herbivores to elevated $\mathrm{CO}_{2}$. Global Change Biology, 3, 51-59.

Donnelly A, Jones MB, Burke JI et al. (2000) Elevated $\mathrm{CO}_{2}$ provides protection from $\mathrm{O}_{3}$ induced photosynthetic damage and chlorophyll loss in flag leaves of spring wheat (Triticum aestivum L., cv. 'Minaret'). Agriculture, Ecosystems and Environment, 80, 159-168.

Eichorn O (1968) Problems of the population dynamics of the silver fir woolly aphids, genus Adelges ( $=$ Dreyfusia). Journal of Applied Entomology, 61, 157-214.

Filion M, Dutilleul P, Potvin C (2000) Optimum experimental design for Free-Air Carbon dioxide Enrichment (FACE) studies. Global Change Biology, 6, 843-854.

Garcia R, Long S, Wall G et al. (1998) Photosynthesis and conductance of spring-wheat leaves: field response to continuous free-air atmospheric $\mathrm{CO}_{2}$ enrichment. Plant Cell and Environment, 21, 659-669.

Gate IM, McNeill S, Ashmore MR (1995) Effects of air pollution on the searching behaviour of an insect parasitoid. Water, Air and Soil Pollution, 85, 1425-1430.

Hansen R, Williams R, Degenhardt D et al. (2001) Non-litter effects of elevated $\mathrm{CO} 2$ on forest floor microarthropod abundances. Plant and Soil, 236, 139-144.

Heagle AS, Brandenburg RL, Burns JC et al. (1994) Ozone and carbon dioxide effects on spider mites in white clover and peanut. Journal of Environmental Quality, 23, 1168-1176.

Hendrey GR, Lewin KF, Nagy J (1993) Free air carbon dioxide enrichment: development, progress, results. Vegatatio, 104/105, 17-32.

Herms DA, Mattson WJ, Karowe DN et al. (1995) Variable performance of outbreak defoliators on aspen clones exposed to $\mathrm{CO}_{2}$ and $\mathrm{O}_{3}$. In: Meeting of the Northern Global Change Program (eds Hom J, Birdsey R, O'Brian K), pp. 43-55. USDA Forest Service, Northeastern Forest Experimental Station, General Technical Report.

Holopainen JK, Kainulainen P, Oksanen J (1995) Effects of gaseous air pollutants on aphid performance on Scots pine and Norway spruce seedling. Water Air and Soil Pollution, 85, 1431-1436.

Holopainen JK, Kössi S (1998) Variable growth and reproduction response of the spruce shoot aphid, Cinara pilicornis, to increasing ozone concentrations. Entomologia Experimentalis et Applicata, 87, 109-113.

Holton MK (2001) Effects of elevated carbon dioxide and ozone on tree-insect-parasitoid interactions. MSc thesis, University of Wisconsin-Madison, USA.

Hughes L, Bazzaz FA (2001) Effects of elevated $\mathrm{CO}_{2}$ on five plant-aphid interactions. Entomologia Experimentalis et Applicata, 99, 87-96.

Intergovernmental Panel on Climate Change (2001) Climate Change 2001: The Scientific Basis. Report of Working Group I of the Intergovernmental Panel on Climate Change. http:// www.ipcc.ch/pub/spm22-01.pdf.

Joern A, Behmer ST (1998) Impact of diet quality on demographic attributes in adult grasshoppers and the nitrogen limitation hypothesis. Ecological Entomology, 23, 174-184.

Kainulainen P, Holopainen J, Holopainen T (2000) Combined effects of ozone and nitrogen on secondary compounds, amino acids, and aphid performance in Scots pine. Journal of Environmental Quality, 29, 334-342.

Kangasjärvi J, Talvinen J, Utriainen M et al. (1994) Plant defence systems induced by ozone. Plant, Cell and Environment, 17, 783-794. 
Kopper BJ, Lindroth RL, Nordheim EV (2001) $\mathrm{CO}_{2}$ and $\mathrm{O}_{3}$ effects on paper birch (Betulaceae: Betula papyrifera Marsh.) phytochemistry and white-marked tussock moth (Lymantriidae: Orgyia leucostigma J.E. Sm.) performance. Environmental Entomology, 30, 1119-1126.

Kopper B, Lindroth RL (2003) Responses of trembling aspen (Populus tremuloides) phytochemistry and aspen blotch leaf miner (Phyllonorycter tremuloidiella) performance to elevated levels of atmospheric $\mathrm{CO}_{2}$ and $\mathrm{O}_{3}$. Agricultural and Forest Entomology 5, 17-26.

Krupa S, McGrath M, Andersen C et al. (2001) Ambient ozone and plant health. Plant Disease, 85, 4-12.

Lawton JH (2000) Community Ecology in a Changing World. Ecology Institute, Germany.

Leather SR (1988) Size, reproductive potential and fecundity in insects: things aren't as simple as they seem. Oikos, 51, 386-389.

Lindroth RL (1996) Consequences of elevated atmospheric $\mathrm{CO}_{2}$ for forest insects. In: Carbon Dioxide, Populations and Communities (eds Körner C, Bazzaz FA), pp. 347-361. Academic Press, London.

Littell R, Milliken G, Stroup W et al. (1996) SAS System for Mixed Models. SAS Institute, Cary, NC, USA.

MacGillivray ME, Anderson GB (1957) Three useful insect cages. Canadian Entomologist, 89, 43-46.

Makino A, Mae T (1999) Photosynthesis and plant growth at elevated levels of $\mathrm{CO}_{2}$. Plant and Cell Physiology, 40, 999-1006.

Newman JA, Gibson DJ, Hickam E et al. (1999) Elevated carbon dioxide results in smaller populations of the bird cherryoat aphid Rhopalosiphum padi. Ecological Entomology, 24, 486-489.

Norby R, Cotrufo M (1998) A question of litter quality. Nature, 396, 17-18.

Parry D, Goyer R, Lenhard G (2001) Macrogeographic clines in fecundity, reproductive allocation, and offspring size of the forest tent caterpillar Malacosoma disstria. Ecological Entomology, 26, 281-291.

Percy KP, Awmack CS, Lindroth RL et al. (2002) Altered performance of forest pests under $\mathrm{CO}_{2^{-}}$and $\mathrm{O}_{3}$-enriched atmospheres. Nature, 420, 403-407.

Radford PJ (1967) Growth analysis formulae - their use and abuse. Crop Science, 7, 171-175.
Reich PB, Knops J, Tilman D et al. (2001) Plant diversity enhances ecosystem responses to elevated $\mathrm{CO}_{2}$ and nitrogen deposition. Nature, 410, 809-812.

Roth SK, Lindroth RL (1995) Elevated atmospheric $\mathrm{CO}_{2}$ : effects on phytochemistry, insect performance and insect-parasitoid interactions. Global Change Biology, 1, 173-182.

Salt DT, Fenwick P, Whittaker JB (1996) Interspecific herbivore interactions in a high- $\mathrm{CO}_{2}$ environment: root and shoot aphids feeding on Cardamine. Oikos, 77, 326-330.

Salt DT, Whittaker JB (1995) Populations of root-feeding aphids in the Liphook forest fumigation experiment. Plant, Cell and Environment, 18, 321-325.

Sequeira R, Dixon AFG (1996) Life history responses to host quality changes and competition in the Turkey-oak aphid, Myzocallis boerneri (Hemiptera: Sternorrhyncha: Callaphididae). European Journal of Entomology, 93, 53-58.

Stacey D, Fellowes M (2002) Influence of elevated $\mathrm{CO}_{2}$ on interspecific interactions at higher trophic levels. Global Change Biology, 8, 668-678.

Stiling P, Rossi AM, Hungate B et al. (1999) Decreased leaf-miner abundance in elevated $\mathrm{CO}_{2}$ : reduced leaf quality and increased parasitoid attack. Ecological Applications, 9, 240-244.

Traicevski V, Ward S (2002) The effect of past and current hosts on reproductive investment by the adult cowpea aphid Aphis craccivora. Ecological Entomology, 27, 601-607.

Ward SA, Dixon AFG (1982) Selective resorption of aphid embryos and habitat changes relative to lifespan. Journal of Animal Ecology, 51, 859-864.

Way MJ, Cammell M (1970) Aggregation behaviour in relation to food utilization by aphids. In: Animal Populations in Relation to Their Food Source (ed. Watson A), pp. 229-247. Blackwell, Oxford.

Whittaker JB, Kristiansen LW, Mikkelden TN et al. (1989) Responses to ozone of insects feeding on a crop and a weed species. Environmental Pollution, 62, 89-102.

Wojciechowicz-Zytko E, van Emden HF (1995) Are aphid mean relative growth rate and intrinsic rate of increase likely to show a correlation in plant resistance studies? Journal of Applied Entomology, 119, 405-409.

Zhang J, Liu J, Wang G et al. (2001) Effect of elevated atmospheric $\mathrm{CO}_{2}$ concentration on Rhopalsiphum padi population under different soil water levels. Yingyong Shengtai Xuebao, 12, 253-256. 